慶應義塾大学学術情報リポジトリ

Keio Associated Repository of Academic resouces

\begin{tabular}{|c|l|}
\hline Title & $\begin{array}{l}\text { Demonstration of functional role of TECK/CCL25 in T lymphocyte-endothelium interaction in } \\
\text { inflamed and uninflamed intestinal mucosa. }\end{array}$ \\
\hline Sub Title & $\begin{array}{l}\text { 炎症時および非炎症時の腸管粘膜におけるTリンパ球と血管内皮との相互作用におけるTECK/CCL2 } \\
\text { 5の役割 }\end{array}$ \\
\hline Author & 細江, 直樹(Hosoe, Naoki) \\
\hline Publisher & 慶應医学会 \\
\hline Publication year & 2004 \\
\hline Jtitle & 慶應医学 (Journal of the Keio Medical Society). Vol.81, No.4 (2004. 12),p.33- \\
\hline JaLC DOI & \\
\hline Abstract & \\
\hline Notes & 号外 \\
\hline Genre & Journal Article \\
\hline URL & https://koara.lib.keio.ac.jp/xoonips/modules/xoonips/detail.php?koara_id=AN00069296-2004120 \\
& 2-0033 \\
\hline
\end{tabular}

慶應義塾大学学術情報リポジトリ(KOARA)に掲載されているコンテンツの著作権は、それぞれの著作者、学会または出版社/発行者に帰属し、その権利は著作権法によって 保護されています。引用にあたっては、著作権法を遵守してご利用ください。

The copyrights of content available on the KeiO Associated Repository of Academic resources (KOARA) belong to the respective authors, academic societies, or publishers/issuers, and these rights are protected by the Japanese Copyright Act. When quoting the content, please follow the Japanese copyright act. 


\section{Demonstration of functional role of TECK/CCL25 in T lymphocyte-endothelium interaction in inflamed and uninflamed intestinal mucosa. \\ (炎症時および非炎症時の晹管粘膜におけるTリンパ球と 血管内皮との相互作用におけるTECK/CCL25の役割)}

\section{細 江 直 澍}

\section{内容の要旨}

近年、組能特罢的なリンパ球ホーミンクにおいて、リンパ球指向 住C-Cケモカインの関与が示唆されてきたが、生体内の胆管におけ る证明は少ない。本研究は、TECK (Thymus-expressed chemokine) / CCL25とそのリガンドCCR9が、マウス胆粘嘠においてTリンパ球の

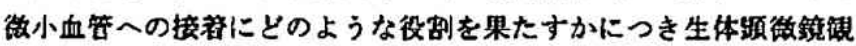
察により検期することを目的とした。小得より粘腊固有局リンパ球 LPL (Lamina Proprial Lymphocyte) 、胆宫上皮内リンパ球 IEL (Intraepithelial Lymphocyle) をそれぞれ分能し、Carboxyfluorescein

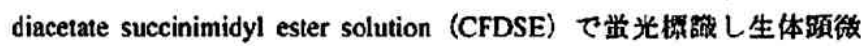

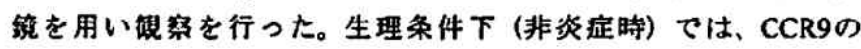
desensitizationによるCCR9の阻害もしくは抗TECK/CCL25中和抗体投 与により、TECKJCCL.25-CCR9システムを虺択的に阳客すると、小 渴において粘㸟钼小血管へのLPL、IELの接著数が娍少したが、大嵒 においては接著数の诚少は㥸められなかった。Tumor necrosis factor alpha (TNF- $\alpha$ 投与) により、小怔、大脂粘娦においてLPLの有意な 接着数の增加を路めたが、IELでは有意な增加を跑めなかった。 TNF- $\alpha$ 投与による炎㱏時においても、CCR9のdesensitization或いは抗 TECK/CCL.25中和抗体投与により、小胆においてのみLPL、IELの粘

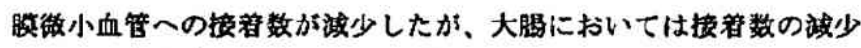
は照めらなれなかった。RT-PCR法により mRNAレベルでLPL、IEL 上のCCR9の発現が朁められた。Chemotaxis assayの結梁、LPL、IEL 上のCCR9をdesensitizationすると、他のケモカインレセブターは阻客 (cross desensitization) されず、TECK/CCL25に対するLPL、IELの走

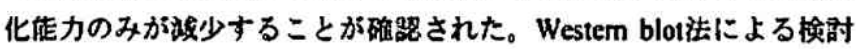

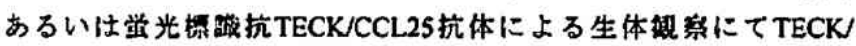

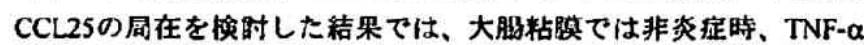
投与時とも、TECK/CCL25の発現は路めなかったが、小胆站胯固有 居においては、TNF- $\alpha$ 投与により、正常時と比校しTECKNCCL25の 発現舟の增加が䀔められた。以上の結果、非炎症時、炎症時とも に、TECK/CCL25-CCR9システムが小胆粘榙德小血管へのTリンパ球

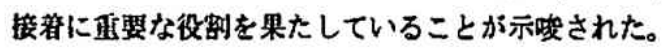

\section{論文单㭗の要旨}

C-CケモカインTECK (Thymus-expressed chemokine) /CCL251は、胸 獥絧胞のほかに小胆での高い発現が艆告されている。本研究は、 TECK/CCL25とそのリガンドCCR9が、マウス胆站膜においてTリンパ 球ホーミングにどのよう役割を果たすかにつき生体㩆微鏡廐察を 用いて比較検吋した。TECK/CCL25-CCR9システムを造択的に阻宫す る方法として、Desensitization techniqueによるCCR9の阻宫もしくは抗 TECK/CCL25中和抗体投与を行った。TECK/CCL25-CCR9システムを 诲抧的に阻客すると生理条件下、また、TNF一投与による炎庭時にお いても、小朋において站膜微小血管へのLPL、IELの接洛数が娍少した が、大熶においては接猪数の娍少は略められなかった。Westem blot法

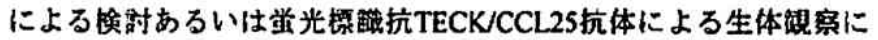
てTECK/CCL25の用在を模郡した結果では、大渴粘娦ではTECKJ

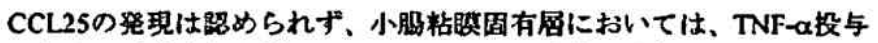

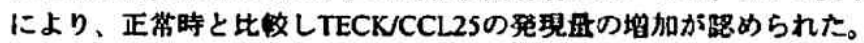
本研究において、非炎症時、炎症時ともに、TECK/CCL25-CCR9シス

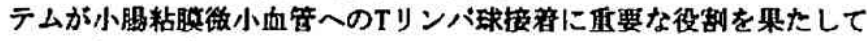
いることが示嘫された。

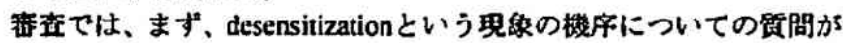
あった。それに対し、文献上は、過盾のTECK/CCL25を长時間作用さ せることにより、リンハ球上のケモカインレセブターCCR9の感度の 低下が起こり、さらに、レセプター自体が細胞内に取り込まれるとさ れていると回答された。

次に、TNFー $\alpha$ 投与によりLPLの有剪な接备数の增加を㥸めたが、IEL では有意な增加を睼めなかった理由についての䆩問があり、LPLと

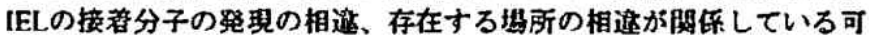
能性があると回答された。

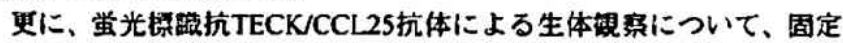
された標本でも、TECK/CCL25の局在を比校树すへきだったのでは ないかとの指摘があった他、他践器での篗察の有無について質間が あったのに対して、今回の锤察では行っていないが、過去の生体艮察 では行っており、他茷器へリンバ球が捕捉されないことは矿恕してい ると回答した。しかしながら、 desensitizationを行ったリンパ球が他剭

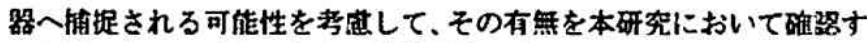
べきだったのではないかとの指摘があった。

以上のように、本研究には今後さらに険的すへき点があるものの、 TECK/CCL25-CCR9システムが小脂粘㬴微小血管へのTリンパ球接着 に卧要な役割を果たしていることを明らかにした点で消化器病学上 有思学な研究であると訐価された。

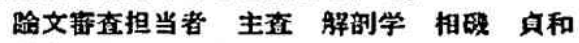

微生物学・免疫学 石川 博通 微生物学・兔度学 小安 国夫 医化学 末松 践

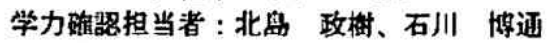

箱查委只长: 石川博通

研究指箱者 : 石井 浴正 (内科学)

誠問日: 平成16年 6 月16日 